\title{
AN ANALYSIS ON FISHERY CAPTURE LICENSING TOWARD THE REGISTRATION AND MARKING OF FISH-TRANSPORTING VESSELS WITHIN THE SOUTH KALIMANT AN PROVINCE AUTHORITY
}

\author{
Siti Dian Amalia \\ Master of Fisheries Science, Fisheries and Marine Faculty \\ Lambung Mangkurat University, Banjarbaru, South Kalimantan, Indonesia \\ JI. A. Yani Km. 36 PO. Box 6 Banjarbaru 70714 \\ Email: s2perikanan_unlam@yahoo.co.id
}

\begin{abstract}
This study aimed to (1) identify the distribution of fish-transporting vessels under the authority of South Kalimantan Province; (2) to analyze the causes of unregistered and unmarked fish-transporting vessels within the provincial authority; and (3) to analyze the causes of fishery capture licensing that continues to run without a Fishing Vessel Book (Buku Kapal Perikanan - BKP). This research activity was conducted at the Banjarmasin Fishing Port, Pelambuan Village, Banjarmasin Barat District, Banjarmasin City, South Kalimantan, with the fish-transporting vessel's owners within the South Kalimantan authority as the research object. The data collected were the data sourced directly from the observation result in the research location, and other supporting data related to the research object. The results showed that the spreading of fish-transporting vessels that land their cargo at the Banjarmasin Fishing Port were found in Kotabaru Regency, Tanah Bumbu Regency, Tanah Laut Regency, Banjar Regency, Barito Kuala Regency, and Banjarmasin City. Based on the data, there are 183 fish-transporting vessels within South Kalimantan Province authority, but only 42 vessels or $23 \%$ ships that are registered as fishing vessels. While for the marking of the vessels, $100 \%$ have not carried out marking as fishing vessels. This is due to the unavailability of a standard BKP and the lack of understanding from the vessel owners. The Licensing of Fishery Capture in the form of SIUP and SIKPI is still issued by BPTSP using only recommendation from Department of Fisheries and Maritime Affairs of South Kalimantan Province. The registration and marking of fish-transporting vessels of South Kalimantan Province Authority are not optimal due to the unavailability of a standard BKP that can be used as collateral so that a policy is needed from the local government in terms of budgeting funds for the procurement of BKP so that fish-transporting vessels in South
\end{abstract}

Kalimantan Province can be registered and marked as Indonesian fishing vessels.

Keywords: fish-transporting vessels owners within South Kalimantan Province authority, registration and marking of vessels

\section{INTRODUCTION}

Indonesia is an archipelago country where the livelihoods of most of the people are fishermen. As an archipelagic country, Indonesia has extensive waters and includes various types of fish resources. Although it is included in the renewable resources, the amount of the resources is not unlimited. In addition to being limited by natural environmental problems, the fish resources are strongly influenced by human activities, especially with the increasing demand for animal protein resources for human needs. Furthermore, the high pressure of fishing due to the presence of foreign fishing fleets that practice illegal fishing accelerates the rate of decline in fish resources stock (Director of Fishing Vessels and Fishing Gear DJPT, 2009)

Fishermen as the livelihoods of Indonesian people are certainly not separated from fishing vessels, where fishing vessels include fishing vessels, fish-transporting vessels and fisheries support vessels. Indonesian fishing vessels or Indonesian legal entities operated for capture fisheries business activities in the Fisheries Management Area of Republic Indonesia (Wilayah Pengelolaan Perikanan Republik Indonesia - WPP-RI) and/or the high seas must be registered as an Indonesian fishing fleet.

The operating regulation on the fishing vessels operated in the WPP-RI and/or the high seas is one of the efforts to ensure an efficient (profitable) capture fisheries business system, by striving to optimize the availability of fish resources (stock) with the catch level (effort) in each catchment areas, as mandated in Law No. 45/2009 concerning amendments to Law No. $31 / 2004$ concerning Fisheries and the Code of 
Conduct for Responsible Fisheries (CCRF, FAO 1995), which states that sustainable and responsible fisheries management needs to be carried out by marking the fishing vessels.

Fishing vessels carrying out fishing and transporting activities are required to register and mark the fishing vessels. Vessel registration is the recording of fishing vessel that are contained in the Fishing Vessel Book (Buku Kapal Perikanan - BKP), BKP is a book that contains information on the results of the fishing vessels registration that contained fishing vessel data and owner's identity as well as changes to the fishing vessel's physical and documents (MMAF Regulation No. 17, 2008).

Regulations concerning the registration and marking of fishing vessels have been in place since 2009, but for South Kalimantan Province, only fishery vessel registration has been carried out while the fishing vessel marking has not yet been carried out even though The Department of Fisheries and Maritime Affairs of the Province of South Kalimantan always conducts socialization activities on registration and marking of fishing vessels which aim to register the fishing vessels to obtain BKPs and be registered as Indonesian fishing vessels.

Formulation of The Problem are:

1. The data unavailability on the distribution of fish-transporting vessels within the authority of the South Kalimantan Province.

2. Registration and Marking of fish-transporting vessels within the provincial authority has not been carried out in accordance with the MMAF Regulation No. PER.27/MEN/2009 concerning registration and marking of fishing vessels and renewed with MMAF Regulation No. 23/PERMEN-KP/2013 concerning registration and marking of fishing vessel.

3. Capture Fisheries Licensing continues to run even without a BKP. If there is no permit, it means that the vessel is not registered, so the catch of unregistered vessels means that illegal fishing that causes the percent of catch loss to be unpredictable or equal to lost regional income.

The purposes of the research are to:

1. Identify the distribution of fish-transporting vessels in the authority of the South Kalimantan Province.

2. Analyze the causes of fish-transporting vessels in the authority of South Kalimantan Province have not been registered and marked.

3. Analyze the causes of capture fisheries licensing that keep running without BKP.

\section{MATERIALS AND METHODS}

The method used in this study is descriptive, which is a method that aims at solving problems that exist in the present to an object by collecting data, compiling, analyzing, explaining and drawing conclusions (Nasir, 2003). The secondary data collection in this study was carried out at the Department of Fisheries and Maritime Affairs of South Kalimantan Province and the One-Stop Integrated Service Agency (Badan Pelayanan Terpadu Satu Pintu - BPTSP) while the primary data was carried out at the Banjarmasin Fishing Port in South Kalimantan Province. The respondents are fish-transporting vessel owners within the provincial authority, namely 10 - 30 GT vessel in Banjarmasin Fishing Port. The selection of sample locations and respondents was determined by purposive sampling method (intentionally) because almost all fishtransporting vessels leaned/docked at the Banjarmasin Fishing Port. Respondents who were interviewed amounted to 20 (twenty) people from 183 owners of fish-transporting vessels.

The data collected in the form of primary data and secondary data. Primary Data was obtained directly from respondents through interviews using a questionnaire that has been prepared, while secondary data was the data obtained from reports and official documents from institutions related to the research. Secondary data come from the capture fisheries statistics annual report of the Department of Fisheries and Maritime Affairs of the South Kalimantan Province and licensing data were from South Kalimantan Province BPTSP. These data are SIUP and SIKPI licensing data, Vessel Book data, Ship Registration and Marking data and data relating to research objectives.

\section{RESULTS AND DISCUSSION}

Based on data with respondents who were interviewed in the field and the secondary data available, the following results are obtained: 
Siti Dian Amalia: An Analysis on Fishery Capture Licensing Toward The Registration and ...

Table 1. Fishing Vessels Data in South Kalimantan

\begin{tabular}{llrrrr}
\hline No. & Regency/City & $5-10$ GT & $10-20$ GT & $20-30$ GT & $>30$ GT \\
\hline 1. & Tanah Laut & 254 & 160 & 13 & 25 \\
2 & Banjar & 268 & - & - & - \\
3. & Barito Kuala & 106 & 24 & 13 & 6 \\
4. & Tanah Bumbu & 140 & 33 & 11 & - \\
5. & Banjarmasin & 187 & - & - & - \\
6. & Kotabaru & 988 & 20 & 2 & 3 \\
\hline Total & & & & 39 & 34 \\
\hline
\end{tabular}

Source: Capture Fisheries Statistics Report

Table 2. Licensing of Capture Fisheries Within Provincial Authority

\begin{tabular}{rrrrrrl}
\hline No. & Year & \multicolumn{2}{c}{ Type Of License } & \multicolumn{2}{c}{ Total } & \\
& & SIUP & SIPI & SIKPI & & \\
\hline 1. & 2010 & 86 & 4 & 82 & 86 & Diskanlut \\
2. & 2011 & 182 & 24 & 158 & 182 & Diskanlut \\
3. & 2012 & 193 & 29 & 164 & 193 & Diskanlut \\
4. & 2013 & 191 & 36 & 155 & 191 & KP2T \\
5. & 2014 & 189 & 45 & 144 & 189 & KP2T \\
6. & 2015 & 361 & 178 & 183 & 361 & BPTSP \\
\hline
\end{tabular}

Source: BPTSP of South Kalimantan Province in 2015

Table 3. Registration of Fishing Vessels

\begin{tabular}{ccccc}
\hline No. & Year & \multicolumn{2}{c}{ Vessels Type } & Total \\
& & Capture & Transport & \\
\hline 1. & 2010 & 3 & 42 & 45 \\
2. & 2011 & 3 & 42 & 45 \\
3. & 2012 & 3 & 42 & 45 \\
4. & 2013 & 3 & 42 & 45 \\
5. & 2014 & 3 & 42 & 45 \\
6. & 2015 & 3 & 42 & 45 \\
\hline
\end{tabular}

Source: Capture Fisheries Division, Dept. Fisheries and Maritime Affairs of South Kalimantan, 2015

Table 4. Marking of Fishing Vessels

\begin{tabular}{ccccc}
\hline No. & Year & Capture & Vessels Type & Total \\
\hline 1. & 2010 & 0 & 0 & 0 \\
2. & 2011 & 0 & 0 & 0 \\
3. & 2012 & 0 & 0 & 0 \\
4. & 2013 & 0 & 0 & 0 \\
5. & 2014 & 0 & 0 & 0 \\
6. & 2015 & 0 & 0 & 0 \\
\hline
\end{tabular}

Source: Capture Fisheries Division, Dept. Fisheries and Maritime Affairs of South Kalimantan, 2015 
Table 5. Fish-transporting Vessels Owner Respondents

\begin{tabular}{|c|c|c|c|c|}
\hline No. & Vessel's Owner & $\begin{array}{l}\text { SIUP and SIKPI } \\
\text { License }\end{array}$ & $\begin{array}{l}\text { Vessel } \\
\text { Registration }\end{array}$ & Vessel Mark \\
\hline 1. & GIAN & Yes & Not yet & Not yet \\
\hline 2. & H. BAHRUNI & Yes & Not yet & Not yet \\
\hline 3. & NURDIN & Yes & Not yet & Not yet \\
\hline 4. & ROFI'I & Yes & Not yet & Not yet \\
\hline 5. & H. RUSTAM & Yes & Not yet & Not yet \\
\hline 6. & JAMILUDIN & Yes & Not yet & Not yet \\
\hline 7. & YASIR HADI BRATA & Yes & Not yet & Not yet \\
\hline 8. & MASRIANSYAH & Yes & Not yet & Not yet \\
\hline 9. & RUSDIANSYAH & Yes & Not yet & Not yet \\
\hline 10. & ERNAWATI & Yes & Not yet & Not yet \\
\hline 11. & RASIDI & Yes & Done & Not yet \\
\hline 12. & H. DARHAM & Yes & Done & Not yet \\
\hline 13. & H. USMAN & Yes & Done & Not yet \\
\hline 14. & H. MUDE & Yes & Not yet & Not yet \\
\hline 15. & ABDUL RAHMAN & Yes & Not yet & Not yet \\
\hline 16. & DJAHRANI & Yes & Not yet & Not yet \\
\hline 17. & LINDA & Yes & Not yet & Not yet \\
\hline 18. & H. JAMALUDIN & Yes & Not yet & Not yet \\
\hline 19. & Hj. FALAH & Yes & Done & Not yet \\
\hline 20. & H. ATONG & Yes & Not yet & Not yet \\
\hline
\end{tabular}

Source: Primary data processed, 2016

Based on the vessel's distribution data in Table 1, there are 246 ships with the size of 10 30 GT in the South Kalimantan Province, which are spread in 6 (six) Regencies namely Kotabaru, Tanah Bumbu, Tanah Laut, Banjar, Barito Kuala and Banjarmasin City. In table 1, the data only shows the number of fishing vessels consisting of fishing vessels and transporters, there is no specific data for the distribution of fish-transporting vessels within South Kalimantan Province authority. The activity base is in Banjarmasin Fishing Port. Based on the structure, South Kalimantan fishing fleet has more transport vessels than fishing vessels.

Based on the fishing vessels registration and marking activities in Tables 3 and 4, there were only $12 \%$ or 45 of 361 that had SIUP, SIPI and SIKPI licenses from $2010-2015$. Out of 183 units of fish-transporting vessels, 42 units or around $23 \%$ have already been registered. Meanwhile, $100 \%$ vessels, marking activities have not been carried out. Based on interviews with vessels owner respondents in table 5 , out of 20 (twenty) respondents only 4 (four) people had already carried out vessel registration activities while the fishing vessel marking had not yet been carried out. The low registration of fishing vessels, especially fish-transporting vessels are due to the absence of standard BKP that can be used as collateral so that sanctions cannot be applied, while the absence vessels marking is because the fishermen expect the government to also facilitates in the form of paint aid such as giving free BKP. It has been explained in the MMAF Regulation that the marking is carried out by the vessel owner alone, but due to low education, fishermen consider it all facilitated by the government. Whereas, based on the MMAF Regulation No: PER.27/MEN/2009 and renewed with the MMAF Regulation No: PER.23/MEN/2013, fishing vessels that have not carried out the registration and marking activities are not permitted to carry out fishing activities, either fishing or transportation. The BKP currently available is still in the form of temporary BKP and cannot be used as collateral because they are not in accordance with the standards. Besides that, the number of BKPs cannot meet all the fishing vessels, both fishing vessels and transporters that have SIUP, SIPI and SIKPI permits. The absence of funds from the South Kalimantan Provincial Government also caused this activity could not be implemented optimally, because in the implementation of this activity there must be a standard BKPs from the MMAF that is BKP with barcodes such as BPKB as vessel ownership proof. Where later, it can be used as collateral by the owner of the transport vessels to increase the operational capital to transport fish.

The obligation to register vessels (physical inspection of the vessel) by the licensing officer is an absolute requirement to obtain a BKP. Later, it can be used as a condition in the issuance of SIPI/SIKPI specifically within the central government authority, namely the size $>30$ GT. Whereas in South Kalimantan, the 
implementation has not run optimally, because the fishing vessels generally do Markdown or reduce the size of vessels. In the documents, the South Kalimantan fish-transporting vessels are of average size of $>10-30$ GT when in fact after verification and/or re-measurement by the KSOP Class I Banjarmasin the majority is over 30 GT which is within the authority of central government.

In its implementation, vessel registration is an inseparable part of the physical inspection procedure of the vessel, fishing gear, as well as the machine for fishing vessels or palka (hatch) for fish-transporting vessels, accompanied by a physical photograph of the side view with a size of $5 \times 10 \mathrm{~cm}$. The benefits of registration and marking of fish-transporting vessel within the provincial authority is the availability of fisheries vessel distribution data, especially in South Kalimantan, an organized structure of the fishing fleet in each WPP, ensuring the certainty of capture fishing business in a sustainable manner, and the realization of responsible fisheries management and preservation of sustainability fish resources.

Problems arise where the existing Licensing Management System has not been integrated between one agency to another, where it should be. Currently, the licensing system is not optimal in guaranteeing the sustainability of fisheries resources and the carrying capacity of the environment. There is no integrated data and information system related to licensing in the natural resources sector, especially for activities that use coastal space, sea and small islands (DJ-KP3K).

When viewed based on the license numbers of the fishing and fish-transporting vessels in the South Kalimantan Province, especially those that are within the provincial authority for the size of 10-30 GT vessels, all of them have SIUP licenses, namely 361 units consisting of 178 units for SIPI and 183 units for SIKPI which are valid for one year and must be extended. It can be said that the owner of a fishtransporting vessels in South Kalimantan already has an awareness of the importance of licensing because without permission the vessel cannot sail, and they can pay more expensive fees to the authorities if they are raided. For example, in Banjarmasin, having a complete license, they still must pay illegal fees, especially if the documents are incomplete. SIUP and SIKPI Capture Fisheries Licensing are issued by the One-Stop Service Agency (BPTSP) through recommendations from the Department of Fisheries and Maritime Affairs of South Kalimantan Province which must be extended every year. The creation of new licenses and extensions should not be permitted if the fishing vessel has not registered the ship because it is one of the absolute conditions in granting licenses, but BPTSP still issues licenses even though it only recommendations without the registration and marking of the fishing vessels.

\section{CONCLUSIONS}

1. Based on the capture fisheries statistics data from the Department of Fisheries and Maritime Affairs of South Kalimantan Province in 2015, the distribution of fishing vessels under the authority of the South Kalimantan Province in 6 (six) regencies consists of fishing vessels and transporters. There is no specific data on the distribution of fish-transporting vessels. So that there is no known number of transport vessels measuring 10-30 GT, which are actually within the authority of the South Kalimantan Province.

2. The unavailability of standard BKP that can be used as a collateral causes the Fisheries Vessel Registration and Marking activities in the South Kalimantan Province to be not optimal according to the MMAF Regulation No: PER.27/MEN/2009 concerning Registration and Marking of Fishing Vessels and updated with MMAF Regulation No: PER.23/MEN/2013 concerning Registration and Marking of Fishing Vessels. Besides that, the long bureaucracy according to the vessel owner, causes the registration and marking of the fish-transporting vessels within the provincial authority to not be able to work because it passes through two different places.

3. BPTSP still issued SIUP and SIKPI licenses only with recommendations without the registration and marking of fishing vessels.

\section{REFERENCES}

Directorate of Fishing Vessels and Fishing Equipment (2006). MMAF Regulation No: PER.17/MEN/2006 concerning Capture Fisheries Business. Ministry of Maritime Affairs and Fisheries. Jakarta.

Directorate of Fishing Vessels and Fishing Equipment (2009). MMAF Regulation No: PER.27/MEN/2009 concerning Registration and Marking of Fishing Vessels. Ministry of Maritime Affairs and Fisheries. Jakarta. 
Siti Dian Amalia: An Analysis on Fishery Capture Licensing Toward The Registration and ...

Directorate of Fishing Vessels and Fishing

Equipment (2010). Specifications,

Codification and Procedures for

Writing Fishing Vessel Identification.

Directorate General of Capture

Fisheries. Jakarta. 